\title{
Development of a Need Based IVRI-Dairy Manager App and its Perceived Utility
}

\author{
Harshita Sood $^{1 *}$, Rupasi Tiwari ${ }^{1}$, Amandeep Singh $^{2}$ and Triveni Dutt ${ }^{1}$ \\ ${ }^{1}$ Division of Extension Education, ${ }^{2}$ Directorate of Extension Education, Guru Angad Dev \\ Veterinary \& Animal Sciences University, Ludhiana, ICAR-Indian Veterinary Research \\ Institute, Izatnagar, Uttar Pradesh, India \\ *Corresponding author
}

\section{A B S T R A C T}

\begin{tabular}{l} 
Ke y w o r d s \\
Commercial dairy \\
farmers, ICT, \\
Mobile \\
applications, Punjab \\
\hline Article Info \\
$\begin{array}{l}\text { Accepted: } \\
\text { 22 November } 2020 \\
\text { Available Online: } \\
\text { 10 December } 2020\end{array}$ \\
\hline
\end{tabular}

Mobile is today's most popular device for information dissemination owing to the 275 million smart phone subscribers present in India and providing a hope for the improvement of the extension services through the recent advancement in this field, mobile applications and its use. For the development of IVRI- Dairy Manager App, study was conducted in Ludhiana and Chandigarh, the two high productivity regions of Punjab among the commercial dairy farmers. For assessing the perceived utility of the app, a total of 30 commercial dairy farmers were selected randomly as respondents. Semi structured interview schedule and observation method were selected for data collection. The app was developed on the basis of the perceived information needs and the unfelt needs assessed through the gap score in the scientific recommended practices of dairy farming. The app was placed in Google play store on $31^{\text {st }}$ May, 2018. The app has received a high viewers rating. Assessment of the app among the dairy farmers revealed a high average perceived utility score of 19.58. No major constraints were reported for the use of app by dairy farmers. The app can be used as a very good tool for quick referral to scientific management practices and refreshing the knowledge of not only the farmers but also the veterinarians, development organisations which indirectly will help the farmers to increase the productivity and to have enhanced income in the near future.

\section{Introduction}

Dairy farming dominates the livestock sector and is a cardinal pillar of agriculture. Dairy sector has shown a tremendous growth over a span of three decades transforming India from a country of acute milk shortage to world's leading producer (Annual report, DADH\& F, GOI, 2016). But at the same time with the growing population, Planning Commission of
India and NDDB forecast the increase in milk demand from 182 million tons to 200 million tons by the year 2020-21. The biggest hurdle for the dairy farmers is to have access to updated and timely information. Farmers spend a lot of time and money to chase officials for seeking information, which affect their productivity (Singh, 2012 and Misra, 2005). ICT play a key role in disseminating information and have potential to improve 
their productivity. Subash et al., (2015) emphasized the need for effective livestock extension system especially ICT to address the important needs among farmers. Among the ICT tools mobile is gaining much popularity and importance because of ease to access and faster information dissemination. Gensis (2010) stated that $85 \%$ of the respondents use mobile phone to get information on animal husbandry. Mobile phone technology has rapidly extended all over India. It can be a good device to get consultation and advices to improve the animal health and seek information. It can improve the livelihood of farmers. ICT has spread its wings through social media and mobile applications. Mobile app is crucial to dairy farmers in improving their decision making ability to cope up with the changes and meet future challenges of increased milk demand. Teza (2016) conducted study in Chittor district of Andhra Pradesh and concluded that 70 percent of the respondents found that mobile applications were suitable for providing latest and timely information. They are penetrating the animal husbandry sector to have a multidimensional positive impact on information availability and sustainable poverty reduction. Keeping in view all the above facts, a need based mobile application Dairy Manager was developed after assessing the information needs and adoption gap in the scientific management practices of the dairy farmers.

\section{Materials and Methods}

Study was conducted purposely in Punjab state as it accounts for the highest milk productivity of $12.42 \mathrm{~kg} /$ day for exotic and crossbred cattle and $8.21 \mathrm{~kg} /$ day for buffalo in India (BAHF, 2017). Two high productivity regions of Ludhiana and Chandigarh were selected. The sample of the study was commercial dairy farmers who were categorized into two groups having herd size of 25-50 animals and more than 50 animals respectively. Total of 60 respondents, 30 from each group of commercial dairy farmers were selected. Ex post facto research design was used. Snowball sampling technique was used as no list of commercial dairy farmers was available. Data was collected through pre tested semi-structured interview schedule and observation. IVRI Dairy Manager App was developed on the basis of adoption gap in the scientific management practices and perceived information need. For assessing the perceived utility of the app, a total of 30 commercial dairy farmers were selected randomly as respondents from the already selected sample frame. The utility of the app was assessed on seven components. The respondents were asked to give score to each component in three point continuum i.e. Good (3), Fair (2) and Poor (1) and mean score was calculated.

$$
\mathrm{MS}=\underset{\mathrm{i}=1 \mathrm{k}}{\sum \text { Total Score }_{\mathrm{i}}}
$$

Where $\mathrm{k}=$ total number of respondents MS: Mean score

\section{Results and Discussion}

\section{Development of IVRI-Dairy Manager App}

To develop the app prioritization of information needs of dairy farmers in various practices and sub-practices of the dairy farming was done on the basis of Pooled Mean Score (Table 3), a total of 16 subpractices on scientific dairy management (which received pooled mean score of 1.5 and above) were selected for inclusion in the content development of the mobile app. Further unfelt needs were calculated by assessing the gap score in the scientific recommended practices of dairy farming. On 
the basis of the high need scores and gap in scientific practices, a Mobile App was designed and developed for the various aspects of dairy farming. All the content was developed by consulting the relevant literature and content developed was given to a total of 15 experts for validation. After validating all the contents and inserting necessary corrections all related photographs were collected/ shot from the Cattle and Buffalo farm of IVRI and NDRI. Further to enhance the utility of the app in terms of providing lively information and as per the needs of the dairy farmers two Short Videos on Clean milk production and Neonatal calf management in dairy animals were prepared and placed on IVRI Deemed University You Tube Channel on $1^{\text {st }}$ June, 2018 and linked to the App. These videos were developed in both English and Hindi Languages as per the suggestions of the dairy farmers. The language used for mobile application development was Java and the platform used was Android Studio 2.0. The app was finally uploaded on Google play store on May 31st 2018 (Fig. 1 and 2).

Table.1 Distribution of respondents according to the perceived utility of the IVRI-Dairy Manager App

\begin{tabular}{|l|c|c|c|c|}
\hline \multirow{2}{*}{ Perceived utility } & \multicolumn{4}{|c|}{ Dairy farmers (n=30) } \\
\hline Usefulness & Good & Fair & Poor & MS \\
\hline User friendliness & 28 & 2 & 0 & 2.93 \\
\hline Attractiveness & $(93.3)$ & $(6.7)$ & $(0.00)$ & \\
\hline Compatibility & 23 & 7 & 0 & 2.76 \\
\hline Complete coverage of content & $(76.6)$ & $(23.3)$ & $(0.0)$ & \\
\hline Soundness of visuals & 24 & 6 & 0 & 2.80 \\
\hline Credibility & $(80.00)$ & $(20.00)$ & $(0.0)$ & 2.73 \\
\hline Average Perceived Utility Score & 26 & 0 & 4 & 2.80 \\
\hline
\end{tabular}

Table.2 Distribution of respondents according to the problems in accessibility of the IVRI-Dairy Manager App

\begin{tabular}{|l|c|c|c|c|}
\hline \multirow{2}{*}{ Problems in accessibility } & \multicolumn{4}{|c|}{ Dairy farmers (n=30) } \\
\cline { 2 - 5 } & VS & S & NS & MS \\
\hline Technical incompetency & 0 & 2 & 28 & 1.06 \\
\hline Slow functioning of tool & $(0.0)$ & $(6.66)$ & $(93.33)$ & \\
\hline Language problem & 0 & 1 & 29 & 1.03 \\
& $(0.0)$ & $(3.33)$ & $(96.66)$ & \\
\hline Irrelevant information & 6 & 10 & 14 & 1.73 \\
\hline Average accessibility problem score & $(20.00)$ & $(33.3)$ & $(46.66)$ & \\
\hline
\end{tabular}


Table.3 Distribution of respondents according to their information needs on dairy management

\begin{tabular}{|c|c|c|c|c|}
\hline \multirow[t]{2}{*}{$\begin{array}{l}\text { Kind of information } \\
\text { needed }\end{array}$} & \multicolumn{4}{|c|}{$\begin{array}{l}\text { Pooled } \\
\mathrm{N}=60\end{array}$} \\
\hline & Most Needed & Needed & Least Needed & Mean Score \\
\hline $\begin{array}{l}\text { Scientific way of shed } \\
\text { construction }\end{array}$ & $\begin{array}{c}15 \\
(25.00)\end{array}$ & $\begin{array}{c}22 \\
(36.66)\end{array}$ & $\begin{array}{c}23 \\
(38.33)\end{array}$ & 1.87 \\
\hline $\begin{array}{l}\text { Space requirement for } \\
\text { dairy animals }\end{array}$ & $\begin{array}{c}6 \\
(10.00)\end{array}$ & $\begin{array}{c}27 \\
(45.00)\end{array}$ & $\begin{array}{c}27 \\
(45.00)\end{array}$ & 1.64 \\
\hline Breed Selection & $\begin{array}{c}7 \\
(11.66)\end{array}$ & $\begin{array}{c}20 \\
(33.33)\end{array}$ & $\begin{array}{c}33 \\
(55.00)\end{array}$ & 1.56 \\
\hline Infertility problems & $\begin{array}{c}7 \\
(11.66)\end{array}$ & $\begin{array}{c}22 \\
(36.66)\end{array}$ & $\begin{array}{c}31 \\
(51.66)\end{array}$ & 1.59 \\
\hline $\begin{array}{l}\text { Average } \\
\text { requirement }\end{array}$ & $\begin{array}{c}7 \\
(11.66)\end{array}$ & $\begin{array}{c}18 \\
(30.00)\end{array}$ & $\begin{array}{c}35 \\
(58.33)\end{array}$ & 1.53 \\
\hline $\begin{array}{l}\text { Preparation of balanced } \\
\text { ration }\end{array}$ & $\begin{array}{c}11 \\
(18.88)\end{array}$ & $\begin{array}{c}11 \\
(18.88)\end{array}$ & $\begin{array}{c}38 \\
(63.33)\end{array}$ & 1.54 \\
\hline $\begin{array}{l}\text { Fodder preservation and } \\
\text { enrichment }\end{array}$ & $\begin{array}{c}12 \\
(20.00)\end{array}$ & $\begin{array}{c}20 \\
(23.33)\end{array}$ & $\begin{array}{c}28 \\
(46.66)\end{array}$ & 1.73 \\
\hline Care of cow/ buffalo & $\begin{array}{c}9 \\
(15.00)\end{array}$ & $\begin{array}{c}16 \\
(26.66)\end{array}$ & $\begin{array}{c}35 \\
(58.33)\end{array}$ & 1.56 \\
\hline Care of new born calf & $\begin{array}{c}14 \\
(23.33)\end{array}$ & $\begin{array}{c}28 \\
(46.66)\end{array}$ & $\begin{array}{c}18 \\
(30.00)\end{array}$ & 1.93 \\
\hline Hygiene of shed & $\begin{array}{c}9 \\
(15.00)\end{array}$ & $\begin{array}{c}13 \\
(21.66)\end{array}$ & $\begin{array}{c}38 \\
(63.33)\end{array}$ & 1.51 \\
\hline Clean milk production & $\begin{array}{c}24 \\
(40.00)\end{array}$ & $\begin{array}{c}25 \\
(41.66)\end{array}$ & $\begin{array}{c}11 \\
(18.33)\end{array}$ & 2.21 \\
\hline $\begin{array}{l}\text { Common cattle/buffalo } \\
\text { diseases }\end{array}$ & $\begin{array}{c}18 \\
(30.00)\end{array}$ & $\begin{array}{c}21 \\
(35.00)\end{array}$ & $\begin{array}{c}21 \\
(35.00)\end{array}$ & 1.95 \\
\hline Deworming schedule & $\begin{array}{c}8 \\
(13.33)\end{array}$ & $\begin{array}{c}18 \\
(30.00)\end{array}$ & $\begin{array}{c}34 \\
(56.66)\end{array}$ & 1.56 \\
\hline Vaccination schedule & $\begin{array}{c}9 \\
(15.00)\end{array}$ & $\begin{array}{c}14 \\
(23.33)\end{array}$ & $\begin{array}{c}37 \\
(61.66)\end{array}$ & 1.53 \\
\hline $\begin{array}{l}\text { Prevention and control } \\
\text { of diseases }\end{array}$ & $\begin{array}{c}10 \\
(16.66)\end{array}$ & $\begin{array}{c}11 \\
(18.33)\end{array}$ & $\begin{array}{c}39 \\
(65.00)\end{array}$ & 1.51 \\
\hline Government schemes & $\begin{array}{c}10 \\
(16.66)\end{array}$ & $\begin{array}{c}20 \\
(33.33)\end{array}$ & $\begin{array}{c}30 \\
(30.00)\end{array}$ & 1.66 \\
\hline
\end{tabular}

Figures in parenthesis indicate percentage 
Fig.1 Screenshot of ICAR-IVRI Dairy Manager App
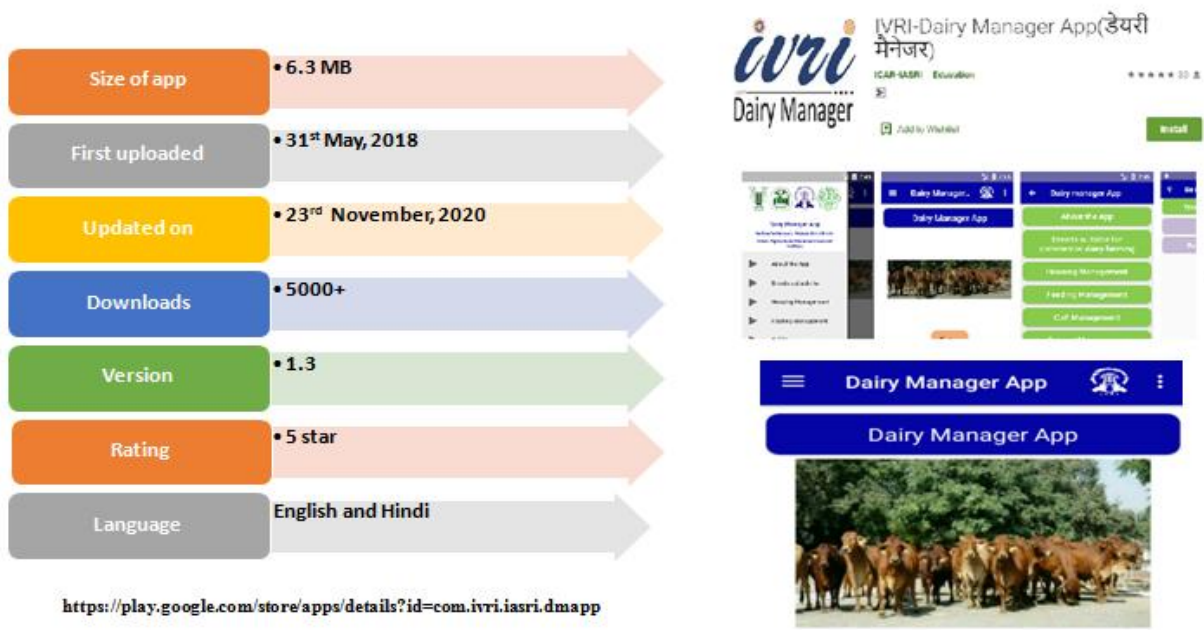

Fig.2 ICAR-IVRI Dairy Manager App analytics
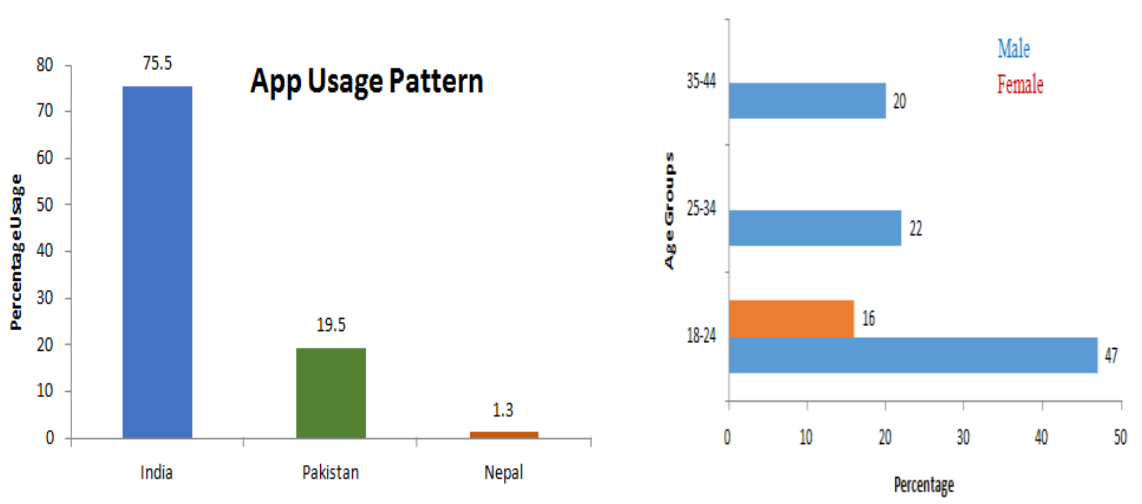

\section{About the IVRI-Dairy Manager App}

The App has been named as IVRI- Dairy Manager App. The Dairy Manager App contains information on Breeds suitable for commercial dairy farming, housing management, feeding management, calf management, general management, clean milk production, animal identification and vices in dairy animals. Further the videos developed and placed on You Tube related to Clean milk production and Neonatal calf management have also been linked to the AI app. The IVRI- Dairy Manager App is available at the URL

https://play.google.com/store/apps/details?id $=$ com.ivri.iasri.dmapp. The present size of the app is $6.3 \mathrm{MB}$. The app was first placed on Google Play store on $31^{\text {st }}$ May 2018 and last updated on $23^{\text {rd }}$ November, 2020 as per user suggestions. This is the 1.3 version of the App. The app presently provides all information in English and Hindi language. The details of the Videos are as follows: Clean milk production (English), Time: 3.04 Min, Clean milk production (Hindi), Time: 3.03 Min, Neonatal calf Management (English), Time: 1.55 Min and Neonatal calf Management (Hindi), Time: 1.55 Min. 


\section{Perceived utility of the developed mobile App}

Perceived utility was studied by sharing the link of developed app with 30 randomly selected commercial dairy farmers from the sampling frame. The respondents were asked about the utility of the developed mobile app and the problems faced by them while using the App. The utility of the app was assessed on seven components like Usefulness, User friendliness, Attractiveness, Compatibility, Complete coverage of content, Soundness of visuals and Credibility. The results (Table 1) revealed that the perceived utility of the App was good with an average perceived utility score of 19.58. Among the seven components, the mean score of usefulness was high with mean score of 2.93 followed by credibility, complete coverage of content and attractiveness with mean score of 2.90 , 2.80 and 2.80 respectively. The results are in agreement with the findings of Mittal et al.(2010) and Kandagar et al.(2018) who reported that ease of use, credibility, usefulness, timeliness and information quality are important attributes that increases the farmers usability of mobile apps. Also Teza (2016) in a study on credibility of information reported that majority of the respondents considered the information available through mobile apps was trustworthy in nature and correct with complete and adequate information. De Silva et al., (2013) and Knoche et al., (2010) reported that focus should be on icons, colour and pictures as most of the farmers memorize signs and symbols rather than text which falls in line with the findings of current research.

\section{Problems faced by the respondents while using the App}

Respondents were asked about the problems faced by them in using the Dairy Manager
App and the results (Table 2) revealed that there was not much problem in using the app as perceived by the respondents though they mentioned some problems viz., language problem and technical incompetency as the hindrance in complete use of the developed App with mean score 1.73 and 1.06 respectively. The average accessibility problem score was 4.85 . The results are in concurrence with Gensis (2010) who conducted a study on potential of mobile phones in utilizing livestock related information and reported that majority of the respondents $(64.16 \%)$ perceived language as major constraint. Anjum (2015) also reported that mobile technology and the language should be designed to be understandable and compatible with the farmers. Language barrier is a major problem in assessing the services and information by the farmers as majority of them have a basic education and can probably read only in their local language. Agwu and Ogbonnah (2015) in Nigeria reported that lack of training opportunities and lack of technical know-how were perceived as serious constraints in the use of ICTs by the respondents.

In conclusion the IVRI- Dairy Manager app was developed after assessing the information needs and adoption gap in the scientific management practices of the dairy farmers. It had received a good user rating of 4.7 out of 5.0 and had crossed more than 5000 downloads in a short period of time. On studying the perceived utility of the app, it was revealed that the perceived utility of app was good with a mean score of 19.58 . Among the seven components, mean score of 'usefulness' was high, followed by 'credibility', 'complete coverage of content' and 'attractiveness'. IVRI -Dairy Manager App has been developed to take care of the information needs of the commercial dairy farmers. It can be a very good tool to be used as quick referral to scientific dairy 
management practices and refreshing the knowledge of dairy farmers at one click. The mobile app can also be used to impart knowledge and skill to graduating Veterinarians, Field Veterinary Officers, Developmental Organisations and Entrepreneurs for promoting scientific dairy farming. To keep a pace with the modern technology, digital revolution and internet penetration has enthralled the farmers to access new apps. Many universities and institutes are working on mobile app development specifically in the area of animal breeding, good animal husbandry practices etc. The digital tools enable farmer to cross geographical boundaries and exchange information with other members of the community.

\section{References}

Agwu, A. E., \& Ogbonnah, E. E. 2015. Access and Use of Information Communication Technologies by Women Staff of Public Extension Service in the North Central Zone of Nigeria. Agricultural Information Worldwide. 6: 18-24.

Anjum, R. (2015). Design of mobile phone services to support farmers in developing countries. Masters Thesis. University of Eastern Finland.

Annual report 2016-2017, DAHD \&F, GOI

Basic Animal Husbandry Statistics 2017.

De Silva, Lasanthi N. C., Goonetillake Jeevani S., Wikramanayake, Gihan N., and Ginige, Athula (2013). Farmer Response towards the Initial Agriculture information Dissemination Mobile Prototype, Computational Science and Its Applications- ICCSA 2013 (pp. 264278).

\section{How to cite this article:}

Harshita Sood, Rupasi Tiwari, Amandeep Singh and Triveni Dutt. 2020. Development of a Need Based IVRI-Dairy Manager App and its Perceived Utility. Int.J.Curr.Microbiol.App.Sci. 9(12): 3003-3009. doi: https://doi.org/10.20546/ijcmas.2020.912.355
Gensis, A.V.I. 2010. Potential of mobile phones in utilization of livestock related information - An exploratory study in Erode district of Tamil Nadu. M.V.Sc thesis, Indian Veterinary Research Institute, Izatnagar.

Knoche Hendrik, PR Sheshagiri Rao, Jeffrey Huang (2010). Voices in the field: A mobile phone based application to improve marginal farmers livelihoods. Retrieved from http://infoscience.epfl.ch/record/173172/f iles/SIMPE_WS_positionPaperKnoche_ ca mera-ready.pdf

Misra, S. (2015). Prospecting Rural ICT business- Drishtee Model. http://digitallearning.in/.

Mittal, S., Gandhi, S. and Tripathi, G. 2010. Socio-economic impact of mobile phones on Indian agriculture. Working Paper 246. New Delhi: Indian Council for Research on International Economic Relations.

Patel, H. and Ppatel, D. (2016). Survey of android apps for agriculture sector, International Journal of Information Sciences and Techniques. 6. 61-67.

Singh, A.K. (2015). Mobile technologies for enriching knowledge and empowering farmers: Experiences of Indian Council of Agriculture research \& other organisations. Accessed: http://www. EAgriculture.

Subash, S., Gupta, Jancy., Babu.G.P., 2015. Information Needs Assessment and Prioritization of Dairy Farmers. J Krishi Vigyan, 4(1): 51-55

Teza, J., Subramanyeswari, B. and Rajanna, N. 2016. Mobile phone using behavior of WSHG members. Journal of Communication Studies, 36(1): 20-27. 